
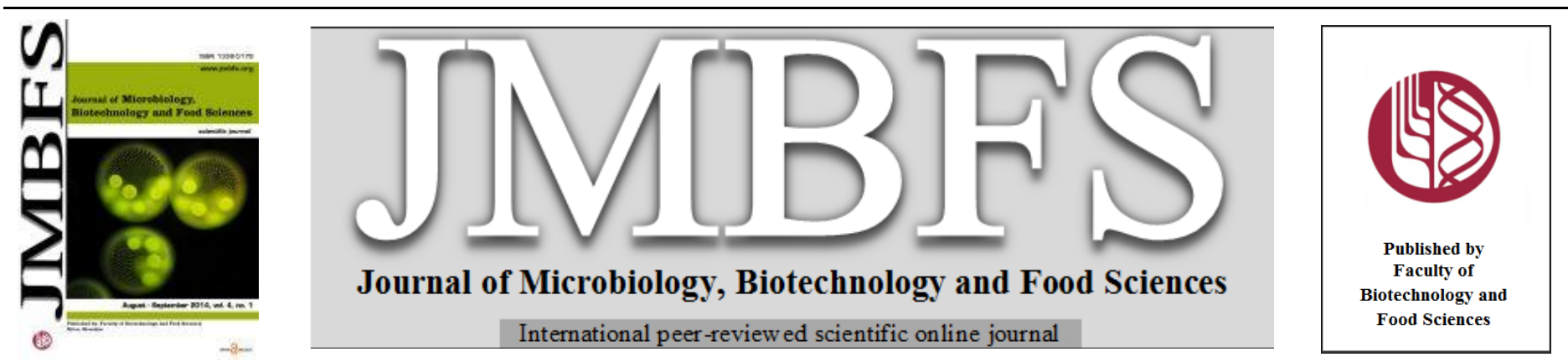

\title{
FATTY ACID CONTENT IN BROILER'S ROSS 308 MEAT MUSCLES AFTER USING BEE POLLEN AND PROBIOTIC AS SUPPLEMENTARY DIET INTO THEIR FEED MIXTURE
}

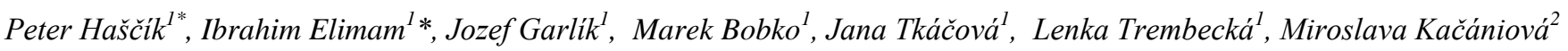

\begin{abstract}
Address(es):
${ }^{1}$ Department of Animal Products Evaluation and Processing, Faculty of Biotechnology and Food Sciences, Slovak University of Agriculture in Nitra, Tr. A. Hlinku 2, 94901 Nitra, Slovak Republic.

${ }^{2}$ Department of Microbiology, Faculty of Biotechnology and Food Sciences, Slovak University of Agriculture in Nitra, Tr. A. Hlinku 2, 94901 Nitra, Slovak Republic.
\end{abstract}

*Corresponding author: peter.hascik@uniag.sk

doi: 10.15414/jmbfs.2014.4.1.67-69

ARTICLE INFO

Received 4. 6. 2014

Revised 17. 7. 2014

Accepted 21. 7. 2014

Published 1. 8. 2014

Regular article

OPEN $\partial_{\text {ACCESS }}$

\begin{abstract}
The present experiment was aimed to study the effect of the bee pollen and probiotic on broiler's meat fatty acid. A total of 120 one day old chicks, which were divided into 4 groups $(\mathrm{n}=30)$. Central, E1 (400 mg.kg ${ }^{-1}$ bee pollen), E2 (3.3 g probiotic) and E3 $\left(400 \mathrm{mg} \cdot \mathrm{kg}^{-1}\right.$ bee pollen $+3.3 \mathrm{~g}$ probiotic) of complete feed mixture, the probiotic has been added through drinking water. After 42 days broiler has been slaughtered to determine meat fatty acid concentrations. We found that the probiotic was increased about (78.9\%) of the essential fatty and bee pollen was increased about (68.4\%) of essential fatty acid in the experimental groups and there were found significant differences $(\mathrm{P} \leq 0.05)$ in monounsaturated acid (MUFA), heptadecanoic acid and omega- 6 between control and E1groups. The mixed between bee pollen and probiotic were reduce the content of the essential fatty acid. However, bee pollen and probiotic were decreased nonessential fatty acid in broiler meat muscles and they were found significant difference ( $\mathrm{P} \leq 0.05)$ in saturated fatty acid (SFA) between control and E1, also between control and myristic acid. It was concluded that the bee pollen and probiotic have increased the fatty acid and decrease the non essential fatty acid in broiler meat muscles.
\end{abstract}

Keywords: Broiler Ross 308, fatty acid, bee pollen, probiotic, monounsaturated

\section{INTRODUCTION}

For good humans health and other animals must ingest essential fatty acid, because their body can't synthesize fatty acid (Robert et $\boldsymbol{a l}$., 1980). To support human health, meat should be processed from the meat content high amount of MUFs, by feeding animal with a feed mixture rich of fatty acid (Aronal et al., 2012). Fatty acid are important sources of the body fuel because, when metabolized they yield large quantities of ATP and many cell types can use either glucose or fatty acid for this purpose in particular heart and skeletal muscle prefer fatty acid, despite longstanding assertions to the contrary, the brain can use fatty acid as a source of the fuel in addition to glucose and ketone bodies (Robert $\boldsymbol{e t}$ al., 1980; Ebert et al., 2003; Isaac et al., 2012). It has been observed that the consumption of chickens of diets with different fatty acid composition not only changes the degree of saturation, but also modifies the amount of fat deposited in chicken tissues. In particular the intake of the polyunsaturated fatty acid (PUFA) compared to the intake of saturated fatty acid (SFA) causes a lower fat deposition in the animal (Villaverde et al., 2005).

Bee pollen is rich of the a major fatty acid, presented as mean values were $\mathrm{C} 18: 3$ (25.1\%), C16:0 (19.6\%), C18:1 (17.3\%), C18:2 (8.78\%), C22:0 (4.07\%) and $\mathrm{C} 18: 0(2.96 \%)$ acids. The proportions of $\mathrm{C} 18: 3$ were generally higher than those of $\mathrm{C} 18: 2$ and the ratio of total unsaturated fatty acid (TUS) to total saturated fatty acid (TS) was >1.0, except for Nelumbo nucifera Gaertn, pollen for the characteristic absence of C18:3 acids (Yang et al., 2013). Probiotics are microorganisms that have claimed health benefits when consumed (Ringo et al. 1998). Probiotic increases the (PUA) fatty acid (Bomba $\boldsymbol{e t}$ al., 2002). Despite a substantial amount of the basic and clinical research on the beneficial effects of probiotics all of the evaluated claim applications thus far have received a negative opinion. With the restrictions on the use of the clinical endpoints, validated biomarkers for gut health and immune health in relation to reduction in disease risk are needed. Clear-cut criteria for design as well as evaluation of the future studies are needed. An open dialogue between basic and clinical scientists, regulatory authorities, food and nutrition industry, and consumers could bridge the gap between science and marketing of probiotics (Rijkers et al., 2011).
The study was objected to study the effect of addition the bee pollen into feed mixture and probiotic through drinking water on the broiler's meat essential fatty acid.

\section{MATERIAL AND METHODS}

The experiment was implemented at the test poultry station of Slovak University of Agriculture in Nitra. The tested chickens were broiler Ross 308. The experiment included 120 chicks in one day-old, which were divided into 4 groups $(\mathrm{n}=30)$ : control, E1 (400 mg.kg-1 natural bee pollen), E2 (3.3 g probiotic) E3 (400 mg.kg ${ }^{-1}$ natural bee pollen $+3.3 \mathrm{~g}$ probiotic) the probiotic has been added through drinking water. In all the investigated groups the chickens were fed by same starter complete feed mixture (CFM) HYD-01 (loose structure) from $1^{\text {st }}$ day to $21^{\text {st }}$ days of their age and grower from the $22^{\text {nd }}$ to $42^{\text {nd }}$ days of their age (Table 1).

The chickens were bred in cage conditions. Each cage was equipped with feed dispenser and water intake was ensured ad libitum through a self feed-pump. The temperature was controlled during the fattening period and it was $33^{\circ} \mathrm{C}$ at the first day and every week was reduced about $2{ }^{\circ} \mathrm{C}$ and final temperature was 19 ${ }^{\circ} \mathrm{C}$. The lighting during the experimental period was continuous. The experiment duration was 42 days.

At the end of the fattening period from each experimental group were selected 20 pieces of chickens for slaughter analysis $(10+$ pieces and 10 pieces $\precsim)$, to evaluate the count of fatty acid of the broiler's meat muscles. The experimental analyses in Animal Production Research Centre Nitra (APRC Nitra) by using Agilent 7890A Gas Chromatograph (USA).

\section{Statistical analysis}

The results of meat performance (arithmetic mean, standard deviation) were statistically analysed by the statistic program Statgraphics Plus version 5.1 (AV Trading Umex, Dresden, Germany). For the determination of significant differences among the tested groups was used analysis of variance. 
Table 1 Composition of the broiler feed mixture

\begin{tabular}{|c|c|c|}
\hline Ingredients (\%) & $\begin{array}{c}\text { Starter } \\
(1 \text { to } 21 \\
\text { days of age) }\end{array}$ & $\begin{array}{c}\text { Grower } \\
(22 \text { to } 42 \\
\text { days of age) }\end{array}$ \\
\hline Wheat & 35.00 & 35.00 \\
\hline Maize & 35.00 & 40.00 \\
\hline Soybean meal $(48 \% \mathrm{~N})$ & 21.30 & 18.70 \\
\hline Fish meal $(71 \% \mathrm{~N})$ & 3.80 & 2.00 \\
\hline Dried blood & 1.25 & 1.25 \\
\hline Ground limestone & 1.00 & 1.05 \\
\hline Monocalcium phosphate & 1.00 & 0.70 \\
\hline Fodder salt & 0.10 & 0.15 \\
\hline Sodium bicarbonate & 0.15 & 0.20 \\
\hline Sodium bicarbonate & 0.15 & 0.20 \\
\hline Lysine & 0.05 & 0.07 \\
\hline Methionine & 0.15 & 0.22 \\
\hline Palm kernel oil Bergafat & 0.70 & 0.16 \\
\hline${ }^{1}$ Premix Euromix BR 0,5\% & 0.50 & 0.50 \\
\hline \multicolumn{3}{|l|}{ Analysed composition $\left({\mathrm{g} . \mathrm{kg}^{-1}}^{-1}\right)$} \\
\hline Crude protein & 210.76 & 190.42 \\
\hline Fibre & 30.19 & 29.93 \\
\hline Ash & 24.24 & 19.94 \\
\hline $\mathrm{Ca}$ & 8.16 & 7.28 \\
\hline $\mathrm{P}$ & 6.76 & 5.71 \\
\hline $\mathrm{Mg}$ & 1.41 & 1.36 \\
\hline $\operatorname{ME}\left(\mathrm{MJ} \mathrm{kg}^{-1}\right)$ & 12.02 & 12.03 \\
\hline
\end{tabular}

${ }^{1}$ active substances per kilogram of premix: vitamin A $2500000 \mathrm{IU}$; vitamin E $50000 \mathrm{mg}$; vitamin D3 $800000 \mathrm{IU}$; niacin $12000 \mathrm{mg}$; d-pantothenic acid $3000 \mathrm{mg}$; riboflavin 1800 $\mathrm{mg}$; pyridoxine $1200 \mathrm{mg}$; thiamine $600 \mathrm{mg}$; menadione $800 \mathrm{mg}$; ascorbic acid $50000 \mathrm{mg}$; folic acid $400 \mathrm{mg}$; biotin $40 \mathrm{mg}$; vitamin B12 $10.0 \mathrm{mg}$; choline $100000 \mathrm{mg}$; betaine 50000 mg; Mn 20000 mg; Zn 16000 mg; Fe 14000 mg; Cu 2400 mg; Co 80 mg; I 200 mg; Se 50 mg.

\section{RESULTS}

In humans the fatty acid is a principle energy substrate and structural component of cell membranes (phospholipids) and second messengers, fatty acid are also ligands of nuclear receptors affecting gene expression (Kremmyda et al., 2011). However, table (2) shows the fatty acid content of the broiler's meat muscles after were used bee pollen as a supplemental diet into broiler's feed mixture and probiotic were added through drinking water. It was found that the palmitoleic acid, oleic acid, monounsaturated (MUFAs) and omega-3 were higher in the experimental groups compared to control group and they found significant differences $(\mathrm{P} \leq 0.05)$ in monounsaturated (MUFAs) between control and $\mathrm{E} 1$ groups. Also they were found that the myristoleic acid, arachidonicacid, heptadecanoic acid, nervonic acid, cis-11,14-eicosadienoicacid, cis-8,11,14eicosatrienoic acid and cis-5,8,11,14,17 eicosapentaenoic in the experimental groups were higher than control group except E3 it was lower than the control group and they were found significant differences $(\mathrm{P} \leq 0.05)$ in myristoleic acid between E1 and E3 groups, also in heptadecanoic acid there were found significant differences $(\mathrm{P} \leq 0.05)$ between $\mathrm{E} 1$ and control, E2 and E3 groups.

On the other hand, in elaidic acid they were found that the experimental E1 was higher than the control, but E2, E3 groups it were a lower than the control group and there were found significant differences $(\mathrm{P} \leq 0.05)$ between $\mathrm{E} 1$ and $\mathrm{E} 2$ groups. However, the linoleic acid and $\alpha$-linolenic acid were higher in control than E1, E2 and E3 groups. Further, the polyunsaturated (PUFAs) were higher in E2 group compared to control, except E1, E3 it were a lower than control. The linoelaidic acid and pentadcanoic acid were higher in the E1, E3 groups compared to the control group except the E1 group. Moreover, the cis-11-eicosenoic acid was higher in the E1 group than the control group, but E2 and E3 were a lower compared to control group. Otherwise, the omega- 6 was higher in E2 that control and experimental E1, E3 were a lower than the control group.

Table (3) shows the effect of the bee pollen and probiotic on broiler's meat saturated fatty acid, where were found that the myristic acid, palmitic acid, stearic acid and saturated fatty acid (SFA) in the control group were higher compared to experimental groups and it were found significant differences $(\mathrm{P} \leq 0.05)$ in myristic acid between $\mathrm{E} 3$ and control and $\mathrm{E} 1$, also in saturated fatty acid (SFA) were found significant differences $(\mathrm{P} \leq 0.05)$ between control and $\mathrm{E} 1$ group.

Table 2 The effect of bee pollen $\left(400 \mathrm{mg} \cdot \mathrm{kg}^{-1}\right)$ and probiotic $(3.3 \mathrm{~g})$ on broiler Ross 308 unsaturated fatty acids (\%)

\begin{tabular}{|c|c|c|c|c|}
\hline Indicators & Control & $\begin{array}{c}\text { E1 } \\
\text { pollen }\end{array}$ & $\begin{array}{c}\mathrm{E} 2 \\
\text { probiotic }\end{array}$ & $\begin{array}{c}\text { E3 } \\
\text { pollen+probiotic }\end{array}$ \\
\hline Myristoleic acid & $0.211 \pm 0.18^{\mathrm{ab}}$ & $0.225 \pm 0.20^{\mathrm{a}}$ & $0.230 \pm 0.0 .03^{\mathrm{ab}}$ & $0.209 \pm 0.01^{\mathrm{b}}$ \\
\hline Palmitoleic acid & $7.011 \pm 0.63$ & $7.317 \pm 0.73$ & $7.452 \pm 0.81$ & $7.291 \pm 0.37$ \\
\hline Oleic acid & $40.733 \pm 0.88$ & $41.239 \pm 0.8$ & $40.791 \pm 1.50$ & $41.356 \pm 0.92$ \\
\hline Elaidic acid & $0.119 \pm 0.05^{\mathrm{ab}}$ & $0.146 \pm 0.06^{\mathrm{a}}$ & $0.984 \pm 0.05^{\mathrm{b}}$ & $0.113 \pm 0.01^{\mathrm{ab}}$ \\
\hline Linoleic acid & $11.491 \pm 0.53$ & $11.148 \pm 0.58$ & $11.385 \pm 1.01$ & $11.077 \pm 0.82$ \\
\hline Linoelaidic acid & $0.121 \pm 0.03$ & $0.106 \pm 0.05$ & $0.134 \pm 0.01$ & $0.135 \pm 0.02$ \\
\hline$\alpha$-Linolenic acid & $0.753 \pm 0.02$ & $0.743 \pm 0.044$ & $0.730 \pm 0.07$ & $0.737 \pm 0.05$ \\
\hline Arachidonic acid & $0.372 \pm 0.20$ & $0.377 \pm 0.18$ & $0.416 \pm 0.21$ & $0.308 \pm 0.11$ \\
\hline Pentadcanoic acid & $0.087 \pm 0.04$ & $0.052 \pm 0.05$ & $0.088 \pm 0.03$ & $0.839 \pm 0.04$ \\
\hline Heptadecanoic acid & $0.105 \pm 0.04^{\mathrm{a}}$ & $0.061 \pm 0.05^{\mathrm{b}}$ & $0.109 \pm 0.01^{\mathrm{a}}$ & $0.101 \pm 0.02^{\mathrm{a}}$ \\
\hline Nervonic acid & $0.317 \pm 0.17$ & $0.367 \pm 0.19$ & $0.350 \pm 0.18$ & $0.270 \pm 0.10$ \\
\hline cis-11-eicosenoic acid & $0.454 \pm 0.04$ & $0.483 \pm 0.07$ & $0.446 \pm 0.04$ & $0.447 \pm 0.03$ \\
\hline Cis-11,14-Eicosadienoic acid & $0.208 \pm 0.07$ & $0.224 \pm 0.08$ & $0.222 \pm 0.07$ & $0.193 \pm 0.05$ \\
\hline Cis-8,11,14-eicosatrienoic & $0.160 \pm 0.06$ & $0.166 \pm 0.09$ & $0.181 \pm 0.07$ & $0.152 \pm 0.05$ \\
\hline Cis-5,8,11,14,17 Eicosapentaenoic & $0.146 \pm 0.04$ & $0.160 \pm 0.03$ & $0.162 \pm 0.04$ & $0.145 \pm 0.02$ \\
\hline Polyunsaturated (PUFAs) & $13.252 \pm 0.75$ & $12.924 \pm 0.71$ & $13.320 \pm 1.18$ & $12.749 \pm 0.97$ \\
\hline Monounsaturated (MUFAs) & $48.845 \pm 1.02^{\mathrm{a}}$ & $49.776 \pm 0.04^{\mathrm{b}}$ & $49.357 \pm 1.47^{\mathrm{ab}}$ & $49.689 \pm 1.05^{\mathrm{ab}}$ \\
\hline Omega-3 & $0.072 \pm 0.001$ & $0.075 \pm 0.002$ & $0.073 \pm 0.002$ & $0.074 \pm 0.002$ \\
\hline Omega-6 & $13.736 \pm 0.31^{\mathrm{a}}$ & $13.398 \pm 0.36^{\mathrm{b}}$ & $13.822 \pm 0.48^{\mathrm{ab}}$ & $13.427 \pm 0.43^{\mathrm{ab}}$ \\
\hline
\end{tabular}

E1, E2, E3: experimental groups; ${ }^{a, b}$ - means with different superscripts differ significantly; $(\mathrm{P} \leq 0.05)$ significant

Table 3 The effect of bee pollen $\left(400 \mathrm{mg} \cdot \mathrm{kg}^{-1}\right)$ and probiotic $(3.3 \mathrm{~g})$ on the broiler Ross 308 saturated fatty acid (\%)

\begin{tabular}{lcccc}
\hline Indicators & Control & $\begin{array}{c}\text { E1 } \\
\text { pollen }\end{array}$ & $\begin{array}{c}\text { E2 } \\
\text { probiotic }\end{array}$ & $\begin{array}{c}\text { E3 } \\
\text { pollen+probiotic }\end{array}$ \\
\hline Myristic acid & $0.694 \pm 0.02^{\mathrm{a}}$ & $0.684 \pm 0.03^{\mathrm{a}}$ & $0.663 \pm 0.05^{\mathrm{ab}}$ & $0.641 \pm 0.01^{\mathrm{b}}$ \\
Palmitic acid & $26.887 \pm 0.51$ & $26.6103 \pm 0.47$ & $26.633 \pm 0.80$ & $26.902 \pm 0.47$ \\
Stearic acid & $6.394 \pm 0.53$ & $6.046 \pm 0.67$ & $6.092 \pm 0.65$ & $6.052 \pm 0.38$ \\
Saturated fatty acids (SFA) & $34.168 \pm 0.68^{\mathrm{a}}$ & $33.453 \pm 0.78^{\mathrm{b}}$ & $33.583 \pm 583^{\mathrm{ab}}$ & $33.787 \pm 0.74^{\mathrm{ab}}$ \\
\hline
\end{tabular}

E1, E2, E3: experimental groups; ${ }^{a, b}$ - means with different superscripts differ significantly; $(\mathrm{P} \leq 0.05)$ significant

\section{DISCUSSION}

Today the meat fatty acid content has become an important factor to measure the poultry meat quality, because fatty acid affecting on human health (Rahimi et al. 2011). The present study gives us data of the fatty acid content of the broiler's Ross 308 meat after using bee pollen ( $\left.400 \mathrm{mg} \cdot \mathrm{kg}^{-1}\right)$ into broiler's feed mixture and probiotic $(3.3 \mathrm{~g})$ through broiler drinking water.
From table (2) it was found that the bee pollen has increased about 13 essential fatty acids such as myristoleic acid, palmitoleic acid, oleic acid,elaidic acid, linoleic acid, arachidonic acid, heptadecanoic acid, nervonic acid, cis-11eicosenoic acid, cis-11,14-eicosadienoic acid, cis-5,8,11,14,17 eicosapentaenoic monounsaturated (MUFAs) and omega-3 and this is about $(68.4 \%)$ of the total essential fatty acid in broiler's meat muscles. The reason why bee pollen has increased the fatty acid because bee pollen is a rich by fatty acid (Loidland and Crailsheim, 2001; Manning, 2001; Teresa, 2006; Yang et al., 2013). 
Moreover, the addition of the probiotic was an increase about 15 essential fatty acids such as myristoleic acid, palmitoleic acid, oleic acid, linoelaidic acid, arachidonic acid, pentadcanoic acid, heptadecanoic acid, nervonic acid, cis 11,14-eicosadienoic acid, cis-8,11,14-eicosatrienoic acid, cis-5,8,11,14,17 eicosapentaenoic, polyunsaturated (PUFAs), monounsaturated, omega-3 and omega-6, in broiler's meat and this representing approximately about (78.9\%) of the total essential fatty acid. This results support by Kankaanpää et al. (2004) who was studied the effect of probiotic on broiler's fatty acid. On the other hand, our study are not in agreement with Zhiping et al. (2003) who was found that the probiotic reduced the fatty acid in rats. The reason why bee pollen increases the fatty acid, because probiotic improve microorganisms in the small intestine and large intestine, which that led to increased polyunsaturated fatty acid (Ringø et al., 1998; Kankaanpää et al., 2001; Bomba et al., 2002).

Otherwise, when we mixed between bee pollen and probiotic they just increase about 6 essential fatty acids such as palmitoleic acid, oleic acid, linoelaidic acid, pentadcanoic acid, monounsaturated and omega-3 and this representing approximately about $31.6 \%$ of the total essential fatty acid. That's because probiotic increase small intestine microorganism (Eamonn et al., 2006), but bee pollen put down the microorganisms (Kačániová et al., 2012). According to these results we suggest that it's better to use bee pollen and probiotic separately. On the other hand, from the table (3) we found that the bee pollen and probiotic were reduced the saturated fatty acid such as myristic acid, palmitic acid, stearic acid and saturated fatty acid (SFA) in broiler's meat. Ross et al. (2012) found that the probiotic decreased (SFA) in pork. Also Pramote et al. (2011) support our results who was found that the probiotic had reduced (SFA) on goats. The reason why bee pollen and probiotic decrease the saturated fatty acid (non essential fatty acid) because bee pollen content flavonoids, and the flavonoids are decrease plasma lipid levels, improve glucose tolerance, and attenuate obesity, one possible mechanism underlying these physiological effects is reduction of the hepatic levels of the mRNA for stearoyl-CoA desaturase(SCD1), since repression of this enzyme reduces hyperlipidaemia and adiposity (Jung et al., 2006; La Nita et al., 2011).

\section{CONCLUSION}

From the recent study it was concluded that the addition of natural bee pollen as a supplement diet into the broiler's feed mixture and probiotic through the drinking water, in the amount (400 mg. $\mathrm{kg}^{-1}$ bee pollen) and (3.3 $\mathrm{g}$ probiotic) have a positive effect on broiler meat muscles because bee pollen and probiotic led to an increase the essential fatty acid and decrease the nonessential fatty acid in broiler's meat muscles. However the mixed between bee pollen and probiotic have given a negative effect on broiler's meat muscles which led to decrease the essential fatty acid.

Acknowledgments: This work was supported by the VEGA grants from the Ministry of Education, Science, Research and Sport of the Slovak Republic, grants VEGA no. 1/0129/13 and by European Community under project no 26220220180: Building Research Centre „AgroBioTech".

\section{REFERENCES}

ARONALA, P., HUDA, N., AHMAD, R. 2012. Amino acid and fatty Acid profiles of peking and muscovy duck meat. International journal of poultry science, 11, 229-236. http://dx.doi.org/10.3923/ijps.2012.229.236

BOMBA, A., NEMCOVA, R., GANCARCIKOVA, S., HERICH, R., GUBA, P., MUDRONOVÁ, D. 2002. Improvement of the probiotic effect of microorganisms by their combination with maltodextrins, fructo-oligosaccharides and polyunsaturated fatty acid. British journal of nutrition; 88Suppl, 1, 95 99. http://dx.doi.org/10.1079/BJN2002634

EAMONN, M., QUIGLEY, M., RODRIGO, QUERA. 2006. Small Intestinal Bacterial Overgrowth: Roles of Antibiotics, Prebiotics, and Probiotics. Gastroenterology, 130, 78 - 90. http://dx.doi.org/10.1053/j.gastro.2005.11.046 EBERT, D., HALLERR, G., WALTON, M. E. 2003. Energy contribution of octanoate to intact rat brain metabolism measured by $13 \mathrm{C}$ nuclear magnetic resonance spectroscopy.The journal of neuroscience: The official journal of the society for neuroscience, 23, 5928 - 35.

ISAAC, MARIN-VALENCIA., LEVI, B. GOOD., QIAN, M. A., CRAIG, R. MALLOY., JUAN, M. PASCUAL. 2012. Heptanoate as a neural fuel: energetic and neurotransmitter precursors in normal and glucose transporter I-deficient (G1D) brain. Journal of cerebral blood flow and metabolism, 33, $175-182$. http://dx.doi.org/10.1038/jcbfm.2012.151

JUNG, U. J., LEE, M. K., PARK, Y. B., KANG, M. A., CHOI, M. S. 2006. Effect of citrus flavonoids on lipid metabolism and glucose-regulating enzyme mRNA levels in type-2 diabetic mice. International journal of biochemistry and cell biology, 38, 1134 -1145. http://dx.doi.org/10.1016/j.biocel.2005.12.002

KAČÁNIOVÁ, M., VUKOVIĆ, N. CHLEBO, R., HAŠČÍK, P., ROVNÁ, K. ČUBON, J., DŽUGAN, M., PASTERNAKIEWICZ, A. 2012. The antimicrobial activity of honey, bee pollen loads and beeswax from Slovakia. Archives of $\begin{array}{lllll}\text { biological } & \text { sciences, } & \text { Belgrade, } & 64, & 927-\end{array}$ http://dx.doi.org/10.2298/abs1203927k
KANKAANPÄÄ, P. E., SEPPO, J., SALMINEN, ISOLAURI, E., KUN, LEE, Y. 2001. The influence of polyunsaturated fatty acids on probiotic growth and adhesion. FEMS Microbiology letters, 194, 149 - 153 http://dx.doi.org/10.1016/s0378-1097(00)00519-x

KANKAANPÄÄ, P., YANG, B., KALLIO, H., ISOLAURI, E., SALMINEN, S 2004. Effects of Polyunsaturated Fatty Acids in Growth Medium on Lipid Composition and on Physicochemical Surface Properties of Lactobacilli. Appl. environ. Microbial, 70, 129 - 136. http://dx.doi.org/10.1128/aem.70.1.129136.2004

KREMMYDA, L. S., TVRZICKA, E., STANKOVA, B., ZAK, A. 2011. Fatty acids as biocompounds: their role in human metabolism, health and disease: a review. part 2: fatty acid physiological roles and applications in human health and disease. Biomed pap med fac univ palacky olomouc czech repub, 155, 195 218. http://dx.doi.org/10.5507/bp.2011.052

LA NITA, A. N., DANIEL, E. J., JOHN, A. M., SHIVENDRA, D. S., LENÉ J. H. 2011. Citrus flavonoids repress the mRNA for stearoyl-CoA desaturase, a key enzyme in lipid synthesis and obesity control, in rat primary hepatocytes. Lipids in health and disease, 10, 10-36. http://dx.doi.org/10.1186/1476-511x-1036

LOIDL, A., CRAILSHEIM, K. 2001. Free fatty acids digested from pollen and trailing in the honey bee (Apis mellifera carnica pollmann) midget. Journal of $\begin{array}{llllll}\text { comparative } & \text { physiology } & \text { B } & 171, & 313 & -\end{array}$ http://dx.doi.org/10.1007/s003600100178

MANNING, R. 2001. Fatty acids in pollen: a review of their importance for honey bees. Bee World, 82, 60 - 75.

PRAMOTE, PAENGKOUM., HAN, Y., TRAIYAKUN, S., KHOTSAKDEE, J., PAENGKOUM, S. 2011. Supplementation of Saccharomyces Cerevisiae or Lactobacillus Acidophilus in Goats Diets. World academy of science, engineering and technology, 59, 1976 -1980.

RAHIMI, S., KAMRAN, AZAD, S. KARIMI., TORSHIZIM, A. 2011. Omega-3 Enrichment of Broiler Meat by Using Two Oil Seeds. Journal of agriculture sciences and technology, 13, $353-365$.

RIJKERS, GER, T., DE VOSWILLEM, M., BRUMMER, ROBERT-JAN., MORELLIM, LORENZO., CORTHIER GERARD. A., MARTEAU, PHILIPPE. 2011. Health benefits and health claims of probiotics: Bridging science and marketing. British journal of nutrition. 106, 1291 - 1296 http://dx.doi.org/10.1017/s000711451100287x

RINGØ, E., BENDIKSEN, H. R., GAUSEN, S. J., SUNDSFJORD, A., OLSEN, R. E. 1998. The effect of dietary fatty acids on lactic acid bacteria associated with the epithelial mucosa and from faecalia of Arctic charr,Salvelinusalpinus (L.). Journal of applied microbiology, 85, 855 - 864 http://dx.doi.org/10.1046/j.1365-2672.1998.00595.x

ROBERT, S. GOODHART., MAURICE, E. SHILS. 1980. Modern Nutrition in Health and Disease $\left(6^{\text {th }}\right.$ ed.). Philadelphia: Lea and Febinger 134-138. ISBN 08121-0645-8.

ROSS, G. R., VAN NIEUWENHOVE, C. P., GONZÁLEZ, S. N. 2012. Fatty acid profile of pig meat after probiotic administration. Journal of agricultural and food chemistry, 60, 5974 - 5978. http://dx.doi.org/10.1021/jf205360h

SZCZÊSNA, T. 2006. Long-chain fatty acid composition of honeybee-collected pollen. Journal of apicultural science, 50, 65 -78.

VILlAVERDE, C., BAUCELlS, M. D., CORTINAS, L., HERVERA, M., BARROETA, A. C. 2005. Chemical composition and energy content of chickens in response to different levels of dietary polyunsaturated fatty acids. Arch anim nutr., 59: 281 -292. http://dx.doi.org/10.1080/17450390500217082

YANG, K. WUD., YE, X., LIU, D., CHEN, J., SUN, P. 2013. Characterization of chemical composition of bee pollen in China. Journal agric food chem., 61, 708 - 18. http://dx.doi.org/10.1021/jf304056b

ZHIPING, LI., SHIQI, YANG., HUIZHI, LIN., JIAWEN, HUANG., PAUL, A., WATKINS, ANN, B., MOSER, CLAUDIO., DE SIMONE, XIAO-YU SONG., ANNA, MAE, DIEHL. 2003. Probiotics and antibodies to TNF inhibit inflammatory activity and improve nonalcoholic fatty liver disease. Hepatology, 37, 343 - 350. http://dx.doi.org/10.1053/jhep.2003.50048 